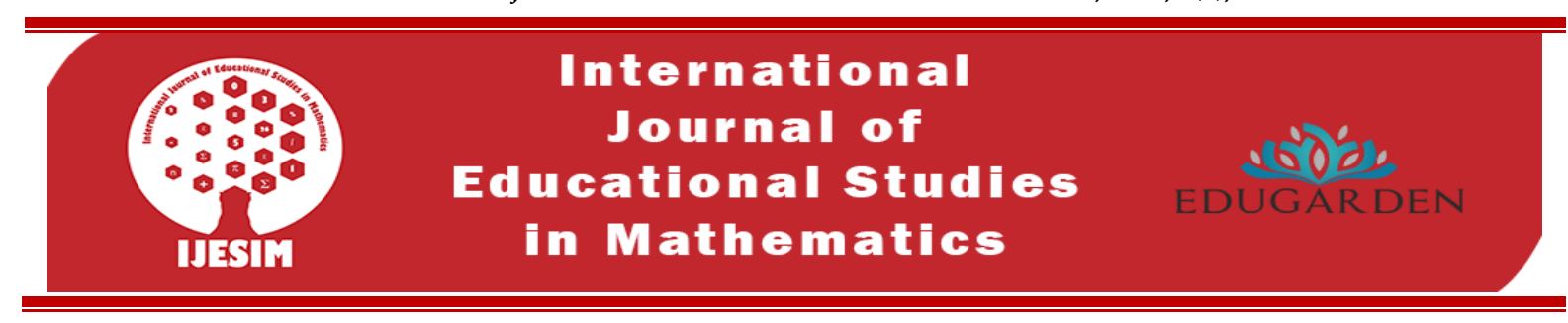

\title{
Investigation of Middle School Students' Perceptions of Value Towards Mathematics Lesson in Terms of Some Variables ${ }^{1}$
}

\author{
Osman Birgin ${ }^{2}(\Phi)$ Hava Öksüz $z^{3(D)}$
}

2 Uşak University, Faculty of Education, Department of Mathematics Education, Uşak, Turkey ${ }^{3}$ Sitkı Çetin Secondary School, Uşak, Turkey

\begin{tabular}{|c|c|}
\hline ABSTRACT & ARTICLE INFO \\
\hline $\begin{array}{l}\text { The aim of this study is to examine the middle school students' } \\
\text { perceptions of value towards mathematics lesson in terms of some } \\
\text { variables. This study was conducted with survey method. The } \\
\text { participants consisted of } 286 \text { middle school students studying in the } \\
\text { province of Uşak, Turkey. Of the participants, } 130 \text { were girls and } 156 \text { were } \\
\text { boys, } 52 \text { were fifth grade, } 59 \text { were sixth grade, } 78 \text { were seventh grade and } \\
97 \text { were eighth grade. Data were collected by using a "Personal } \\
\text { Information Form" and the "Perception of Value Scale for Mathematics } \\
\text { Lesson". Data were analyzed with the SPSS } 17.0 \text { package program using } \\
\text { independent samples t-test, one-way variance analysis (ANOVA), and } \\
\text { Pearson correlation tests. Results of this study showed that middle school } \\
\text { students' perceptions of value towards mathematics lessons were positive } \\
\text { and did not differ significantly according to gender. It was found that } \\
\text { students' perceptions of value differed significantly according to the } \\
\text { grade level, education level of parents and the place of settlement. It was } \\
\text { also found that there was a positive and moderately significant } \\
\text { relationship among perception of value towards mathematics lesson, } \\
\text { mathematics achievement, perception of importance for mathematics and }\end{array}$ & $\begin{array}{l}\text { Article History: } \\
\text { Received: } 19.04 .2020 \\
\text { Received in revised form:05.06.2020 } \\
\text { Accepted:23.06.2020 } \\
\text { Available online: } 26.06 .2020 \\
\text { Article Type: Standard paper } \\
\text { Keywords: middle grade students, } \\
\text { mathematics, values education, gender, } \\
\text { achievement }\end{array}$ \\
\hline loving math teacher. & (C) 2020 IJESIM. All rights reserved \\
\hline
\end{tabular}

\section{Introduction}

Nowadays, one of the duties of the family, society and school is to educate the individuals who have adopted human and universal values. In this context, it is aimed to acquire various knowledge and skills related to cognitive, affective and psycho-motor learning areas in teaching programs. Although cognitive knowledge and skills are given more importance in education than affective attainment, affective attainment has a great impact on human behavior. According to Bean (1990), affective goals include self-perception, values, morality, ethics, beliefs, social tendencies, feelings of appreciation, expectations and attitudes. It was seen that beliefs, attitudes, anxiety and motivation towards mathematics were investigated mostly, but values towards mathematics were not given enough importance (Seah \& Bishop, 2000). Values directly or indirectly affect individuals' behavior and decisions (Fitz Simons, Bishop, Seah \& Clarkson, 2001). For this reason, one of the most important goals of schools is to contribute students to their affective, social and moral development by teaching students value (Akbaş, 2008). The values in mathematics are shaped depending on how much the teacher can apply and maintain the values in the classroom environment (Clarkson, Bishop, FitzSimons \& Seah, 2000). Most of the time, the values are not presented directly in the classroom environment, but they are

${ }^{2}$ Corresponding author's address: Uşak University, Faculty of Education, Department of Mathematics Education, Uşak, Turkey e-mail: osman.birgin@usak.edu.tr

${ }^{1}$ This study is an expanded version of a paper presented at the 4th Turkish Computer and Mathematics Education Symposium held on 26-28 September 2019 in Çeşme, İzmir, Turkey.

DOI: http://dx.doi.org/10.17278/ijesim.723186 
tried to be given implicitly. For this reason, it is very important for the teacher to have pedagogical content knowledge in order to provide effective teaching and gain values (Husband, 1947; Mujs \& Reynolds, 2010). As a matter of fact, teachers decide which decisions are made in the classroom environment, and when and how to respond to reactions.

In recent years, it is important that students gain scientific, social, cultural and moral values in the teaching process (Bishop, 2001; Dede, 2007). In the literature, value is defined by many people in different meanings. Matthews (2001) defined values as tools and precursors of behavior. Halstead and Taylor (2000) define values as principles and actions that guide behavior. Based on these definitions, values can be defined in the most general way as a guide that leads decision making, appreciation and behavior. Values should be gained to students not only in a single course, but in all courses in an interdisciplinary relationship. On the other hand, it can be said that there is no direct emphasis on values education in Turkish mathematics curriculum (Minister of National Education [MEB], 2005; 2009; 2013) before 2018, and it was expressed in part in the context of some affective gains. However, values education was emphasized in the Turkish primary school curriculum updated in 2018. In the mathematics curriculum (MEB, 2018), some examples were also provided to gain values such as justice, sharing, scientific, flexibility, aesthetics, equality, tolerance, freedom, patience, respect, responsibility and savings in mathematics lessons. In this context, it is important to determine secondary school students' perceptions of value towards mathematics lesson.

The aim of this study is to examine the middle school students' perceptions of value towards mathematics lesson in terms of some variables. In this context, answers to the following questions were sought: (a) What is the middle school students' perceptions of value towards mathematics lesson? (b) Do students' value perceptions towards mathematics lesson differ significantly in terms of gender, grade level, settlement and education level of parents? (c) Is there a significantly correlation between students' perceptions of value towards mathematics lesson and mathematics achievement, level of loving teacher and perception of importance mathematics importance?

\section{Method}

This study was conducted with survey methods. The participants consisted of a total of 286 Turkish middle school students at the different settlements in the city of Uşak in the 2018-2019 academic year. Participants consisted of 130 girls and 156 male students; 52 of them were fifth grade, 59 of them were sixth grade, 78 of them were seventh grade and 97 of them were eighth grade students. In terms of settlement, $115(30.1 \%)$ of the participants were in the village and towns, $100(26.2 \%)$ of them were in the district center, 167 (43.7\%) of them were in the city center.

\subsection{Instruments and Data Analysis}

Data were collected with "Personal Information Form" and "Perception of Value Scale" for mathematics applications lesson developed by Aytaçlı and Gündoğdu (2018). In the personal information form, there were questions including the students' gender, class, settlement, grade of math lesson success, education level of mother and father, level of loving mathematics teacher, and level of importance to mathematics lesson. Value perception scale for mathematics lesson consisted of 16 items in 5-point Likert type $(1=$ Strongly disagree, $5=$ Strongly agree). The scale has three sub-dimensions (academic self-confidence, scientific and responsibility) and explains $68 \%$ of the total variance. In this study, the scale was applied for mathematics lesson. In the current study, Cronbach alpha reliability coefficient of the scale was found to be 0.93 . Data were analyzed with SPSS 17.0 package program using t-test, one-way variance analysis (ANOVA) and Pearson correlation test.

\section{Findings, Results and Suggestions}

In this study, it was determined that middle school students' perceptions of value related to the subdimensions of "academic self-confidence" and "scientific" were moderate, and their perceptions of value about the sub-dimension of "responsibility" were high. It was found that middle school students" perceptions of value towards mathematics lesson were moderate level. Similarly, some studies in 
Turkey (Akbaş, 2014; Aktepe \& Yalçınkaya, 2016; Polat \& Çalışkan, 2013; Ünlü \& Metin, 2016) showed that students had high perceptions about individual and social values.

Results of the study showed that middle school students' perceptions of value towards mathematics lesson did not differ significantly according to gender [ $t(380)=1.834, p>$.05]. Similarly, Kabaday and Aladağ (2010) found that there was no significant difference between the male and female students' perceptions of moral value in different educational institutions. Yılmaz, Avşaroğlu and Deniz (2010) determined that pre-service teachers' value preferences did not differ significantly by gender. In this respect, it supports the findings of this research. However, some studies (Akbaş, 2004; Aydın, 1997; Polat \& Çalışkan, 2013; Ünlü \& Metin, 20016) indicated that there was a significant difference in the perceptions of value according to gender. It can be stated in the literature that the value perceptions of female and male students do not show consistency. It can be explained the fact that the political, cultural, belief, expectation, life, personal characteristics and behaviors of the family and social environment of individuals are different.

Results of the study revealed that the middle school students' perceptions of value towards mathematics course differ significantly in terms of grade level $\left[F_{(3-378)}=6.864, p<.01\right]$. It was determined that 5 th grade students had the highest perceptions of value and 8th grade students had the lowest perceptions of value and their perceptions of value decreased as the grade level increased. This finding can be explained by the fact that secondary school students encounter problems with focus and adaptation as a result of adolescence and autonomous personality development process (Özdemir \& Kalayc1, 2013). In addition, 8th grade students' lower perceptions of value towards mathematics lesson compared to other grades can be explained by the fact that High School Entrance Exam (LGS) creates anxiety, stress and pressure especially 8 th grade students. This situation causes low achievement students to adopt negative prejudice, attitude and belief towards mathematics.

It was determined that middle school students' perceptions of value towards mathematics course did differ significantly in terms of settlement $\left[F_{(3-379)}=6.992, p<.01\right]$ and educational level of parents $\left[F_{(3-378)}\right.$ $=5.024, p<.01]$. Accordingly, the students in the provincial and district centers had higher perceptions of value than students in the village and district. This situation can be explained by the fact that students in the city and district centers have many opportunities in terms of cultural, social and academic learning environment (Birgin \& Demirkan, 2017; Karadeniz, 2014) compared to students in the village and town. Many results of studies indicated that the education level of the family positively affected the primary and secondary students' attitudes towards the lessons (Birgin \& Demirkan, 2017), their engagement to the lessons (Birgin et al., 2017; Willms, 2003) and their academic achievements (Çanakç1 \& Özdemir, 2015; Öksüzler \& Sürekçi, 2010; Özer \& Anıl, 2011; Ural \& Çınar, 2014). In this respect, it supports the results of this research.

In addition, it was found that there was a positive and moderately significant correlation between middle school students' perceptions of value and their mathematics achievement $[r=.556, p<.01]$, perception of importance for mathematics $[r=.446, p<.01]$ and level of mathematics teacher loving ( $r$ $=.520, p<.01]$. Similarly, various studies in the literature (Aytaçlı \& Gündoğdu, 2018; Bishop, 2001; Coşkun \& Yıldırım, 2009; England, 2009; Katmış, Ekşi \& Öztürk, 2011; Kunduroğlu, 2010) emphasized that students' value perception positively contributed to their academic success. In addition, many studies (Birgin et al., 2017; Birgin \& Demirhan, 2017; Balantekin \& Oksal, 2014; Kemanc1, 2004; Nicolaidou \& Philippou, 2003; Peker \& Mirasyedioğlu, 2003; Singh, Granville \& Dika, 2002) revealed that students' perceptions of importance and value towards mathematics increased their academic success.

In future studies, students' value towards mathematics lesson in different grade level can be examined in different variables. It can be investigated as to what extent mathematics teachers carry out the applications for value education in the teaching process. 


\section{Ortaokul Öğrencilerinin Matematik Dersine Yönelik Değer Algılarının Bazı Değişkenler Bakımından İncelenmesi ${ }^{1}$}

\author{
Osman Birgin ${ }^{2}\left(\mathbb{D}\right.$, Hava Öksüz $z^{3}(\mathbb{D}$ \\ 2 Uşak Üniversitesi, Eğitim Fakültesi, Matematik Eğitimi Anabilim Dalı, Uşak, Türkiye \\ ${ }^{3}$ Sitkı Çetin Ortaokulu, Uşak, Türkiye
}

MAKALE B İLG İ

\section{Makale Tarihçesi:}

Alınd1:19.04.2020

Düzeltilmiş hali alındı:05.06.2020

Kabul edildi:23.06.2020

Çevrimiçi yayınlandı:26.06.2020

Makale Türü: Standard makale

Anahtar Kelimeler: ortaokul öğrencisi, matematik, değer eğitimi, cinsiyet, başarı

\section{Giriş}

Temel insani ve evrensel değerleri benimsemiş bireylerin yetiştirilmesi aile, toplum ve okulun başlıca görevleri arasında yer almaktadır. Bu nedenle çağdaş eğitim programlarında, bireylerin sosyal, kültürel ve etik davranış ve değerleri kazanması, günlük hayatta karşılaşılan sorunlara çözüm üretmesi, özgüven ve benlik saygısının gelişimi ve demokratik değerleri benimsemesi vurgulanmaktadır. Bu bağlamda öğretim programlarında bilişsel, duyuşsal ve psiko-motor öğrenme alanlarına ilişkin çeşitli bilgi ve becerilerin kazanılması amaçlanmaktadır. Ancak eğitim sistemimizde bilişsel bilgi ve becerilerin daha çok ön plana çıktığı dikkat çekmektedir. Bunun nedeni olarak duyuşsal ve psiko-motor kazanımların bilişsel kazanımlara ulaşmak için bir araç olarak kullanılması gösterilebilir (Dede, 2007). Her ne kadar bilişsel bilgi ve becerilere daha çok önem verilse de duyuşsal kazanımların insan davranışlarının üzerindeki etkisi oldukça fazladır. Duyuşsal öğrenme alanı kapsamında benlik algısı, öz-yeterlik, değer, ahlak, etik, inanç, sosyal eğilim, beklenti, ilgi, kaygı ve tutumlar yer almaktadır (Baki, 2008). İlgili alanyazın çalışmaları incelendiğinde matematiğe yönelik inanç (Çelik ve diğ., 2018; Çevirgen, 2016; İlhan ve Çetin, 2013), tutum (Birgin ve Demirkan, 2017), kaygı (Birgin, Baloğlu, Çatlığlu ve Gürbüz, 2010; Peker ve Mirasyedioğlu, 2003) ve motivasyon (Balantekin ve Oksal, 2014; Demir ve Budak, 2016) gibi birçok duyuşsal özelliklerin ele alındığı ve önem verildiği anlaşılmaktadır.

Son yıllarda öğretim sürecinde öğrencilerin bilimsel, sosyal, kültürel ve ahlaki birçok değerlerin kazandırılması önem kazanmıştır (Bishop, 2001; Dede, 2007). Değer kavramının sosyal bilimler alınyazında farklı yönlerini ön plana çıkaran farklı tanımlamaların yapıldığı görülmektedir. Swadener ve Soedjadi (1988), değerleri tanımlarken "iyi" ve "kötü" gibi bazı kavramlara ihtiyaç olduğunu, değer kavramı ile bir niteliğin kıymetine ilişkin görüş ve yargının ifade edildiğini vurgulamaktadır. Halstead ve Taylor (2000) değer kavramını davranışlara rehberlik eden ilkeler ve eylemler olarak ifade etmişlerdir.

${ }^{1}$ Bu çalışma, 26-28 Eylül 2019 tarihleri arasında İzmir' de gerçekleştirilen 4.Uluslararası Bilgisayar ve Matematik Eğitimi Sempozyumunda sunul an sözlü bildirinin genişletilmiş halidir. 
Ahlaki davranış bağlamında değer; bireyin çeşitli insanları, insanlara ait nitelikleri, istek ve niyetleri, davranışları değerlendirirken başvurduğu bir ölçüt olarak ele alınmaktadır (Güngör, 2010; Yazıcı, 2014). Değerlerin sosyolojik yönünü vurgulayan tanımda ise değer; bir sosyal grubun veya toplumun kendi varlık, birlik, işleyiş ve devamını sağlamak için üyelerinin çoğunluğu tarafından doğru ve gerekli oldukları kabul ve tasdik edilen, onların ortak duygu, düşünce, amaç ve çıkarını yansıtan genelleştirilmiş temel ahlaki ilke veya inançlar olarak ifade edilmektedir (Kızılçelik ve Ejder, 1992). Bu tanımlardan yola çıkarak değerler en genel anlamda karar verme, kıymetini bilme ve davranışlara öncülük eden rehber, bireylerin düşünce, tutum ve davranışlarını yönlendiren ve biçimlendiren bir ölçüt olarak tanımlanabilir. $\mathrm{Bu}$ nedenle değerlerin, bireylerin davranışlarına ve kararlarına dolaylı veya doğrudan etkilemesi söz konusudur (Bishop, Clarke, Corrigan ve Gunstone, 2005). Bu yönüyle okulların en önemli görevi, öğrencilere değeri öğreterek onların ahlaki yönden gelişimine ve disipline edilmesine katkı sağlamaktır (Akbaş, 2008). Bu bağlamda bir okulda etkili eğitim ve öğretimin yapılabilmesi için öğretmenin sahip olduğu pedagojik alan bilgisi ve becerisi oldukça önem arz etmektedir (Bishop, 2001; Mujs ve Reynolds, 2010). Çünkü öğretmen sınıf ortamında hangi kararların ne zaman verileceğine veya hangi tepkilere karşılık nasıl davranılacağına kendisi karar vermektedir (Bishop, Seah ve Chin, 2003).

Günlük hayatımızda önemli bir yeri olan değeri, inançlarımızdan ayırmak oldukça güçtür. Nitekim Bishop, Seah ve Chin (2003) değerleri, insanın yapmış olduğu eylemlerdeki inançlar olarak ifade etmektedir. İnançlarımız yanlış ya da doğru olarak ayrılabilirken değerlerde bu şekilde bir ayrımın yapılması söz konusu değildir. Değerler daha çok günlük yaşamda önemli olan ve önemli olmayan durumlarla ilgilenmektedir (Seah ve Bishop, 2003). Sam ve Ernest (1997) matematik öğretim sürecinde değerleri "kuramsal değerler", "sosyal ve kültürel değerler" ve "kişisel değerler" olmak üzere üç kategoride sınıflandırmıştır (Dede, 2014). Kuramsal değerler; matematiğin kesinlik, sistematiklik ve rasyonellik gibi kuramsal yönünü, matematiksel bilginin özelliklerini, oluşturma ve anlamlandırma süreçlerini ifade etmektedir. Kuramsal değerlerde matematiksel bilginin kesinliği, mantığa uygunluğu, akıl yürütme, ispat ve problem çözme süreçleri önem kazanmaktadır. Sosyal ve kültürel değerler; bireylerin matematik eğitimiyle ilgili toplum ve kültüre yönelik görev ve sorumluluklarını ifade etmektedir. Bu yönüyle dürüstlük, şefkat, llımlılık, saygı duyma, empati kurma, yardımseverlik bu kapsamda ele alınabilir. Kişisel değerler ise bir kişi ve bireyi doğrudan etkileyen kişiye özgü değerlerdir. Bu kapsamda merak, çaba, ısrar, sabır, güven, ilgi, açık fikirlilik, yaratıcılık gibi özellikler ifade edilebilir. Bishop, FitzSimons, Seah ve Clarkson (1999) matematiğe ait değerleri "eğitime ilişkin değerler", "matematiğe ilişkin değerler" ve "matematik eğitimine ilişkin değerler" şeklinde sinıflandırmışlardır. Durmuş, Bıçak ve Çakır (2008), matematik eğitimine ilişkin değerler alanyazından yararlanarak "nesnelci" (davranışçı ve bilişsel yaklaşıma dayanan) ve "öznelci" (oluşturmacı yaklaşıma dayanan) olarak sınıflamışlardır. Nesnellik, kontrol, gizlilik, doğruluk, açıklık nesnelci değerleri; akılcılık, ilerleme, açılık, yaratıcılık, eğlence, esneklik ve açık fikirlilik değerleri ise öznelci değerleri temsil etmektedir.

Türkiye'de 2005 sonrası yapılan matematik dersi öğretim programlarında (MEB, 2005; 2009; 2013) öğrencilere "Matematikle uğraşmaktan zevk alır.", "Matematikle ilgili konuları tartışır.", "Gerçek hayatta matematiğin öneminin farkında olur.", "Matematik öğrenmek isteyen kişilere yardımcı olur." gibi duyuşsal kazanımlar yer almış ve bu kapsamda bazı değerlerin örtük olarak kazandırılması hedeflenmiştir. 2018 yılında uygulamaya konulan matematik dersi öğretim programında ise matematik değerleri açıkça vurgulanarak farklı değerlerin (adalet, paylaşım, bilimsellik, esneklik, estetik, eşitlik, hoşgörü, özgürlük, sabır, saygı, sorumluluk ve tasarruf) matematik derslerinde kazandırılmasına yönelik örneklendirmelere yer verilmiştir. Üstelik matematik dersi öğretim programında "kök değerler" olarak adalet, dostluk, dürüstlük, öz denetim, sabır, saygı, sevgi, sorumluluk, vatanseverlik, yardımseverlik gibi değerler sunulmuştur (MEB, 2018). Bu yönüyle 2018 öğretim programılla birlikte öğretim sürecinde matematik değerlerinin öğrencilere kazandırılması gerektiği vurgulanmıştır.

Alanyazın incelendiğinde öğrencilerin ve öğretmen adaylarının sosyal, etik ve moral değerlere yönelik algılarını inceleyen çeşitli araştırmaların (Akbaş, 2004; Aktepe ve Yalçınkaya, 2016; Aytaçlı, 2018; Calp, 2006; Çoşkun ve Yıldırım, 2009; Kabaday ve Aladağ, 2010; Polat ve Çalışkan, 2013; Ünlü ve Metin, 2016; Yılmaz ve diğ., 2010) yapıldığı görülmektedir. Buna karşın matematik dersine ve matematiğe yönelik 
değerleri inceleyen araştırmalarının sınırlı kaldı̆̆ı (Aktaş ve Argün, 2018; Dede, 2013; Deniz, 2018; Durmuş ve diğ., 2008; Peker Ünal ve Şen, 2019) dikkat çekmektedir. Durmuş ve arkadaşları (2008) fen ve teknoloji, matematik ve sınıf öğretmenleri ile yaptıkları araştırmada öğretmenlerin matematik ve matematik eğitimi bağlamında sahip oldukları oluşturmacı ve pozitivist değerlerin branş, mezun olunan fakülte ve siyasi eğitim değişkenleri bakımından anlamlı fark göstermediği, erkek öğretmenlerin bayan öğretmenlere göre pozitif değerlere daha çok benimsedikleri saptanmıştır. Dede (2013), Türk ve Alman matematik öğretmenleriyle yaptığ 1 araştırmasında öğretmenlerin karar verme sürecindeki ortaya çıan değerleri incelemiş ve araştırma sonucunda "verimlilik", "sosyalleştirme", "otorite-esneklik" ve "cinsiyet farklılığı" ilişkin değer kategorilerini elde etmiştir. Aktaş ve Argün (2018) yaptıkları nitel araştırmada beş ortaokul matematik öğretmeninin sınıf içi uygulamalardaki karar verme sürecinde sergiledikleri matematik değerleri incelemişlerdir. Araştırmada matematik öğretmenlerinin matematiğe ilişkin bazı değerleri kısmen sergiledikleri, bazılarını ise hiç yansıtmadıkları belirlenmiştir. Ayrıca öğretmenlerin karar verme süreçlerinde nesnecilik, kontrol ve açılık değerlerini daha fazla yansıttıkları ortaya çıkmıştır. Benzer şekilde Deniz (2018) yaptığı araştırmasında ortaokul matematik öğretmenlerinin matematik öğretim programında yer alan değerler eğitimine yönelik görüşlerini incelemiştir. Araştırmada matematik öğretmenlerinin değerler eğitiminden haberdar oldukları, ancak matematik derslerinde değerlere yer verirken zorluk yaşadıkları, değerler eğitimiyle ilgili öğretim materyali ve hizmet içi eğitime ihtiyaç duydukları belirlenmiştir. Peker Ünal ve Şen (2019) yaptıkları araştırmada ilköğretim matematik öğretmeni adaylarının matematik kazanımlarına uygun materyaller aracılığı ile değerler eğitimine yönelik görüşlerinin olumlu olduğunu, ancak değer ve kazanıma uygun materyal hazırlama, sunma ile ilgili duygularının ağırlıklı olarak olumsuz olduğunu belirlemişlerdir. Diğer taraftan Polat ve Çalışkan (2013) yaptıkları araştırmada ortaokul öğrencilerinin sahip oldukları değerleri bazı değişkenler bakımından incelemişlerdir. Araştırma sonucunda, kız öğrencilerin güç, hazcılık, geleneksellik ve uyarılım boyutları bakımından değer algılarının erkek öğrencilere göre yüksek olduğu saptanmıştır. Öğrencilerin sınıf düzeyleri bakımından uyarılım boyutu hariç tüm boyutlarda anlamlı bir farklılaşma gözlenmiştir. Ebeveyn eğitim durumuna göre öz yönelim, geleneksellik, uyma, güç, güvenlik ve uyarılım boyutlarında anlamlı bir farklılaşma tespit edilmiştir. Sosyo ekonomik düzeyi bakımından evrensellik, güç, geleneksellik ve uyarılım boyutlarında anlamlı bir farklılaşma saptanmıştır.

Matematik öğretimini etkileyen ve şekillendiren önemli faktörlerden biri öğretmenin öğrenme ve öğretmeye ilişkin sahip olduğu inanç ve değerlerdir (Birgin, 2006; Bishop, 2001; Bishop ve diğ., 2005; Çelik ve diğ., 2018). Öğretim sürecinde öğrencilerin aktif olduğu öğrenci merkezli bir öğretmenin kazandıracağı değerler ile öğretmen merkezli bir öğretmenin öğrencilere kazandıracağ 1 değerler oldukça farklı olacaktır (Durmuş ve diğ., 2008). Bu yönüyle öğretmenin sahip olduğu değerler ve sınıf içi uygulamalar önem kazanmaktadır. Çünkü öğrencilerin matematikle uğraşma veya uğraşmama kararlarında sahip oldukları matematiksel tutum, inanç ve değerler belirleyici olmaktadır (Aktaş ve Argün, 2018; Bishop, Clarke, Corrigan ve Gunstone, 2005; Dede, 2007). Ancak sinıf ortamında değerlerin doğrudan öğretilmesi çoğu zaman mümkün olmamaktadır. Bu nedenle matematik öğretiminde değerler çoğu zaman örtük bir şekilde verilmektedir. 2018 yılında güncellenen ve matematiksel değerlerin ön plana çıkartıldığı matematik dersi öğretim programı ile birlikte öğrencilerin matematik dersine yönelik değer algılarının ne düzeyde olduğunun belirlenmesi önem arz etmektedir.

$\mathrm{Bu}$ araştırmanın amacı, ortaokul öğrencilerinin matematik dersine ilişkin sahip oldukları değer algılarını incelemektir. Bu amaçla aşağıdaki sorulara yanıt aranmıştır.

a) Ortaokul öğrencilerinin matematik dersine ilişkin değer algıları ne düzeydedir?

b) Ortaokul öğrencilerin matematik dersine ilişkin olan değger algıları cinsiyet, sınıf ve yerleşim yerine göre anlamlı fark göstermekte midir?

c) Ortaokul öğrencilerinin matematik dersine yönelik değer alglları anne ve babanın eğitim düzeyine göre anlaml fark göstermekte midir?

d) Ortaokul öğrencilerinin matematik dersine yönelik değer alg̨ları ile matematik başarı notu, öğretmeni sevme ve derse önem verme arasında anlamalı ilişki var mıdır? 


\section{Yöntem}

Ortaokul öğrencilerinin matematik dersine yönelik değer algılarını belirlemeyi amaçlayan bu araştırma, betimsel tarama modeli kullanılarak yürütülmüştür. Betimsel tarama yönteminde araştırılacak olan konu, birey, objeler kendi koşulları içinde olduğu gibi betimlenmeye çalışlır. Bu yönüyle geçmişte ya da günümüzde var olan bir durumu olduğu gibi betimlemeyi amaç edinen araştırmalar için uygun bir modeldir (Karasar, 2004).

\section{1. Çalışma Grubu}

Bu araştırmanın çalışma grubunu Uşak il, ilçe ve köy ve beldeden seçilmiş toplam 382 ortaokul öğrencisi oluşmaktadır. Çalışma grubunun 189'u kız (\%49.5), 193'ü (\%50.5) erkek olup 76'sı (19.9) beşinci sınıfta, 79'u altıncı sınıfta (20.7), 105'i yedinci sınıfta (27.5), 122'si sekizinci sınıfta (31.9) öğrenim görmektedir. Çalışma grubunun yerleşim yeri bakımından 115'i (\%30.1) köy ve belde, 100'ü (\%26.2) ilçe merkezi, 167'si (\%43.7) il merkezinde öğrenim görmektedir. Çalışma grubunun seçiminde sınıf, cinsiyet, yerleşim yeri gibi değişkenler arasında maksimum çeşitlilik sağlanmaya çalışılmıştır.

\subsection{Veri Toplama Araçları}

Bu araştırmada veri toplama aracı olarak "Kişisel Bilgi Formu" ve "Matematik Dersine Yönelik Değer Algısı Ölçeği" kullanılmıştır.

Kişisel Bilgi Formu: Ortaokul öğrencilerinin cinsiyet, sınıf, yerleşim yeri, matematik dersi başarı notu, anne ve babanın eğitim düzeyi, matematik öğretmenini sevme düzeyi, matematik dersine önem verme düzeyinin içeren sorulardan oluşmaktadır. Öğrencilerin matematik öğretmenini sevme düzeyini (1=Hiç, $5=$ Çok) ve matematik dersin önem verme (1=Hiç, $5=$ =çok) belirlemek için $5^{\prime}$ li derecelendirme ölçeği kullanılmıştır. Öğrencilerin matematik başarısı için matematik dersi karne notları kullanılmış olup bu karne notları öğretmenler vasıtasıyla toplanmıştır.

Matematik Dersine Yönelik Değer Algısı Ölçeği: Bu araştırmada Aytaçlı ve Gündoğdu (2018) tarafından matematik uygulamaları dersi kapsamında geliştirilen "Matematik Uygulamaları Değer Algısı Ölçeği" temel alınmıştır. Ölçek, 5'li likert tipinde (1= Hiç Katılmıyorum, 5=Tamamen Katılıyorum) olup toplam 16 maddeden oluşmaktadır. Yapı geçerliği için yapılan açıklayıcı faktör analizi soncunda ölçeğin "akademik özgüven", "bilimsellik" ve "sorumluluk" olmak üzere üç alt boyuta sahip olduğu ve toplam varyansın \%68'ini açıklayabildiği, doğrulayıcı faktör analizi sonucunda da üç alt boyutlu ölçeğin iyi uyum gösterdiği saptanmıştır. Ölçeğin Cronbach alpha güvenirlik katsayısı 0.90 olarak hesaplanmıştır. Bu araştırma kapsamında, ortaokul öğrencilerinin matematik dersine yönelik değer algılarını belirlemek amacıyla matematik uygulamaları değer algısı ölçeğinde yer alan "matematik uygulamaları" ifadeleri "matematik dersi" şekline dönüştürülerek kullanılmıştır. Yeniden yapılan açımlayıcı faktör analizi sonucunda da ölçek maddelerinin orijinal ölçekte olduğu gibi üç alt boyutta toplandığı, faktör yük değerlerinin 0.719 ile 0.819 arasında değiştiği ve toplam varyansın \%69.29'unu açıklayabildiği belirlenmiştir. Bu araştırmada ölçeğin Cronbach alfa güvenirlik katsayısı 0.93 olarak hesaplanmıştır.

\subsection{Verilerin Analizi}

$\mathrm{Bu}$ araştırmada elde edilen verilerin analizinde SPSS 17.0 paket programı kullanılmıştır. Verilerin dağılımının normal olup olmadığı gruptaki öğrenci sayısının 50 ve üzerinde olması nedeniyle Kolmogorov Smirnov testi ile incelenmiş ve normal dağılım gösterdiği belirlenmiştir. Araştırmanın amacı doğrultusunda cinsiyet değişkeni bakımından incelenmesinde bağımsız örneklem t-testi, sınıf, yerleşim yeri, anne ve babanın eğitim düzeyi değişkenleri bakımından incelenmesinde tek yönlü ANOVA testi kullanılmıştır. Tek yönlü varyans analizinin "varyansların homojenliği" varsayımı Levene testi ile incelenmiş olup değişkenlere ait varyansların homojenliği sağlanması nedeniyle gruplar arasındaki ikili karşılaştırmalar için Tukey HSD testi kullanılmıştır. Öğrencilerin değer algılarında karne notu ile öğretmeni sevme ve derse önem verme arasındaki ilişki bakımından Pearson Korelasyon testi kullanılmıştır. Matematik dersi değer ölçeği 5'li likert tipinden olması nedeniyle ölçekten elde değer algı ortalaması 1.00-1.79 arası "Hiç Katılmıorum", 1.80-2.59 arası "Katılmıyorum", 2.60-3.39 arası "Kısmen 
katılıyorum", 3.40-4.19 arası "Katılıyorum", 4.20-5.00 arası “Tamamen Katılıyorum" şeklinde yorumlanmıştır.

\section{Bulgular}

\subsection{Ortaokul Öğrencilerinin Matematik Dersine Yönelik Değer Algıları}

$\mathrm{Bu}$ araştırmada ortaokul öğrencilerinin matematik dersine yönelik değer algılarına ilişkin betimsel istatistik sonuçları Tablo 1'de sunulmuştur.

Tablo 1. Öğrencilerin matematik dersine yönelik değer algıları

\begin{tabular}{lcccc}
\hline Ölçeğin Alt Boyutları & $\mathrm{n}$ & $\overline{\mathrm{x}}$ & $\mathrm{SS}$ & Katılma Düzeyi \\
\hline Akademik Özgüven & 382 & 3.27 & 1.05 & Kismen \\
Bilimsellik & 382 & 3.24 & 1.17 & Kismen \\
Sorumluluk & 382 & 3.81 & 1.00 & Katıllyorum \\
Ölçeğin Tümü & 382 & 3.40 & .91 & Katıllyorum \\
\hline
\end{tabular}

Tablo 1'de görüldüğü gibi ortaokul öğrencilerinin matematik dersine ilişkin "akademik özgüven" ( $\bar{x}=$ 3.27, SS=1.05) ve "bilimsellik" ( $\bar{x}=3.24, S S=1.17)$ alt boyutlarına ilişkin değer algıları "Kısmen katılıyorum" düzeyinde iken, "sorumluluk" alt boyutuna ilişkin değer algıları $(\bar{x}=3.81, \quad S S=1.00)$ "Katılıyorum" düzeyinde yer almaktadır. Öğrencilerin matematik dersine ilişkin genel değer algılarının $(\bar{x}=3.40$, SS=.91) "Katılıyorum" düzeyinde olduğu belirlenmiştir.

\subsection{Cinsiyete Göre Ortaokul Öğrencilerinin Matematik Dersine Yönelik Değer Algıları}

Ortaokul öğrencilerinin matematik dersine yönelik değer algılarının cinsiyet bakımından fark oluşturup oluşturmadığını belirlemek amacıyla t-testi uygulanmış ve sonuçlar Tablo 2' de sunulmuştur.

Tablo 2. Değer algılarının cinsiyet bakımından t-testi sonuçları

\begin{tabular}{lcccccc}
\hline Değişken & $\mathrm{n}$ & $\overline{\mathrm{x}}$ & $\mathrm{SS}$ & $\mathrm{sd}$ & $\mathrm{t}$ & $\mathrm{p}$ \\
\hline K1z & 189 & 3.31 & .91 & 380 & 1.834 & .067 \\
Erkek & 193 & 3.48 & .89 & & & \\
\hline
\end{tabular}

Tablo 2' de görüldüğü gibi yapılan bağımsız örneklemler $t$-testi sonucunda $\mathrm{k} 1 z(\bar{x}=3.31, \mathrm{SS}=.91)$ ve erkek $(\bar{x}=3.48, \quad S S=.89)$ öğrencilerinin matematiğe yönelik değer algıları arasında anlamlı bir fark bulunmamıştır $\left[t{ }_{(380)}=1.834, p>\right.$.05]. Bu bulgu, ortaokul öğrencilerinin değer algılarının cinsiyete göre değişmediğini göstermektedir.

\subsection{Sınıf ve Yerleşim Yerine Göre Öğrencilerinin Matematik Dersine Yönelik Değer Algıları}

Ortaokul öğrencilerinin matematik dersine yönelik değer algılarının sınıf ve yerleşim yeri bakımından anlamlı bir fark oluşturup oluşturmadığı tek yönlü varyans analizi (ANOVA) ve farklılığın kaynağını belirlemek amacıyla da Tukey HSD testi yapılmıştır. Elde edilen sonuçlar Tablo 3’te verilmiştir.

Tablo 3. Değer algılarının sınıf ve yerleşim yeri bakımından ANOVA sonuçları

\begin{tabular}{|c|c|c|c|c|c|c|c|}
\hline Sinif & $\mathrm{n}$ & $\overline{\mathrm{x}}$ & SS & sd & $\mathrm{F}$ & $\mathrm{p}$ & Fark \\
\hline 5.sinif (A) & 76 & 3.66 & .86 & $3-378$ & 6.864 & .000 & $A>D$ \\
\hline 6.sinıf (B) & 79 & 3.52 & .85 & & & & $B>D$ \\
\hline 7.sinif (C) & 105 & 3.45 & .81 & & & & $C>D$ \\
\hline 8.sinif (D) & 122 & 3.11 & .98 & & & & \\
\hline Yerleşim Yeri & $\mathrm{n}$ & $\overline{\mathrm{x}}$ & SS & sd & $\mathrm{F}$ & $\mathrm{p}$ & Fark \\
\hline İl Merkezi (A) & 167 & 3.45 & .91 & $2-379$ & 6.992 & .000 & $\mathrm{~A}>\mathrm{C}$ \\
\hline İlçe Merkezi (B) & 100 & 3.59 & .80 & & & & $\mathrm{~B}>\mathrm{C}$ \\
\hline Köy ve Belde (C) & 115 & 3.15 & .93 & & & & \\
\hline
\end{tabular}

Tablo 3'te görüldüğü gibi ANOVA testi sonucunda ortaokul öğrencilerinin matematik değer algılarının sınıf düzeyleri bakımından anlamlı bir fark bulunmuştur $\left[F_{(3-378)}=6.864, p<.01\right]$. Yapılan Tukey HSD testi sonucunda anlamlı farkın beşinci sınıf, altıncı sınıf ve yedinci sınıf öğrencilerinin sekizinci sınıf öğrencilerine nazaran matematik değer algılarının daha yüksek olduğu belirlenmiştir $(p<.05)$. 
Tablo 3'te görüldüğü gibi ANOVA testi sonucunda ortaokul öğrencilerinin matematik değer algılarının yerleşim yeri bakımından anlamlı bir fark bulunmuştur $\left[F_{(3-379)}=6.992, p<.01\right]$. Yapılan Tukey HSD testi sonucunda anlamlı farkın il merkezi ile ilçe merkezinde öğrenim gören öğrencilerin matematik değer algilarının köy ve belde de öğrenim gören öğrencilere göre daha yüksek olduğu belirlenmiştir $(p<.05)$.

\subsection{Anne ve Babanın Eğitim Düzeyine Göre Öğrencilerinin Matematik Dersine Yönelik Değer Algıları}

Ortaokul öğrencilerinin matematik dersine yönelik değer algılarının anne ve babanın eğitim düzeyi bakımından anlamlı bir fark oluşturup oluşturmadığı tek yönlü varyans analizi (ANOVA) ve farklılığın kaynağını belirlemek amacıyla Tukey HSD testi yapılmıştır. Elde edilen sonuçlar Tablo 4'te verilmiştir.

Tablo 4. Değer algılarının anne ve babanın eğitim düzeyine göre ANOVA sonuçları

\begin{tabular}{|c|c|c|c|c|c|c|c|}
\hline Annenin Eğitim Düzeyi & $\mathrm{n}$ & $\overline{\mathrm{x}}$ & SS & $\mathrm{sd}$ & $\mathrm{F}$ & $\mathrm{p}$ & Fark \\
\hline İlkokul (A) & 116 & 3.23 & .91 & $3-378$ & 5.024 & .002 & $\mathrm{D}>\mathrm{A}$ \\
\hline Ortaokul (B) & 126 & 3.32 & .92 & & & & $\mathrm{D}>\mathrm{B}$ \\
\hline Lise $(\mathrm{C})$ & 79 & 3.54 & .83 & & & & \\
\hline Üniversite (D) & 61 & 3.72 & .89 & & & & \\
\hline Babanın Eğitim Düzeyi & $\mathrm{n}$ & $\overline{\mathrm{x}}$ & SS & $\mathrm{sd}$ & $\mathrm{F}$ & $\mathrm{p}$ & Fark \\
\hline İlkokul (A) & 99 & 3.26 & .92 & 3-378 & 9.541 & .000 & $\mathrm{D}>\mathrm{A}$ \\
\hline Ortaokul (B) & 107 & 3.20 & .80 & & & & $\mathrm{D}>\mathrm{B}$ \\
\hline Lise $(C)$ & 111 & 3.41 & .91 & & & & $\mathrm{D}>\mathrm{C}$ \\
\hline Üniversite (D) & 65 & 3.90 & .86 & & & & \\
\hline
\end{tabular}

Tablo 4'te görüldüğü gibi ANOVA testi sonucunda ortaokul öğrencilerinin matematik değer algıları annenin eğitim düzeyi bakımından anlamlı bir fark bulunmuştur $\left[F_{(3-378)}=5.024, p<.01\right]$. Yapılan Tukey HSD testi sonucunda anlamlı farkın, anne eğitim düzeyi üniversite mezunu olan öğrencilerin, anne eğitim düzeyi ilkokul ve ortaokul olan öğrencilere göre matematik değer algılarının daha yüksek olduğu ve anlamlı olduğu belirlenmiştir $(p<.05)$.

Tablo 4'te görüldüğü gibi ANOVA testi sonucunda ortaokul öğrencilerinin matematik değer algıları babanın eğitim düzeyi bakımından anlamlı bir fark gösterdiği saptanmıştır $\left[F_{(3-378)}=9.541, p<.01\right]$. Yapılan Tukey HSD testi sonucunda anlamlı farkın baba eğitim düzeyi üniversite mezunu olan öğrencilerin, baba eğitim düzeyi ilkokul, ortaokul ve lise mezunu olan öğrencilere göre matematik değer algılarının daha yüksek ve anlamlı olduğu belirlenmiştir $(p<.05)$.

3.5. Ortaokul Öğrencilerinin Matematik Dersi Değer Algıları İle Matematik Karne Notu, Matematik

Dersi Önem Algısı ve Öğretmeni Sevme Düzeyi Arasındaki İlişki

Ortaokul öğrencilerinin matematik dersine yönelik değer algıları ile matematik karne başarısı, matematik öğretmenini sevme düzeyi, matematik önem algısı arasında ilişkiyi belirlemek için Pearson korelasyon testi uygulanmış, elde edilen sonuçlar Tablo 5 'de sunulmuştur.

Tablo 5. Değer algılarına ilişkin Pearson korelasyon testi sonuçları

\begin{tabular}{lccccccc}
\hline Değişken & $\mathrm{n}$ & $\overline{\mathrm{x}}$ & $\mathrm{SS}$ & $\mathrm{MDA}$ & $\mathrm{MB}$ & $\mathrm{MÖA}$ & ÖSD \\
\hline 1. Matematik Değer Algısı (MDA) & 382 & 3.40 & .91 & 1 & $.556^{* *}$ & $.446^{* *}$ & $.520^{* *}$ \\
2. Matematik Başarısı (MB) & 382 & 2.87 & 1.15 & & 1 & $.475^{* *}$ & $.453^{* *}$ \\
3. Matematik Önem Algısı (MÖA) & 382 & 3.02 & 1.16 & & & 1 & $.426^{* *}$ \\
4. Öğretmeni Sevme Düzeyi (ÖSD) & 382 & 2.56 & 1.19 & & & & 1 \\
\hline
\end{tabular}

${ }^{*} p<.05 \quad{ }^{* *} p<.01$

Tablo 5'de görüldüğğ gibi Pearson korelasyon testi sonucunda matematik dersine yönelik değer algısı ile matematik başarısı arasında pozitif yönlü orta düzeyde anlamlı bir ilişki saptanmıştır $[r=.556, p<.01]$. Benzer şekilde matematik değer algısı ile matematik dersi öğretmenini sevme düzeyi $[r=.520, p<.01]$ ve matematik dersi önem algısı $[r=.446, p<.01]$ arasında pozitif yönlü, orta düzeyde anlamlı bir ilişki olduğu 
belirlenmiştir. Buna göre öğrencilerin matematik başarısı, öğretmeni sevme düzeyi ve matematik önem algısı, matematik dersi değer algılarını olumlu yönde etkilemektedir.

\section{Tartışma, Sonuç ve Öneriler}

Ortaokul öğrencilerinin matematik dersine yönelik değer algılarını incelemeyi amaçlayan bu araştırmada öğrencilerinin "akademik öz güven" ve "bilimsellik" alt boyutlarına ilişkin değer algılarının orta düzeyde, "sorumluluk" alt boyutuna ilişkin değer algılarının ise yüksek olduğu belirlenmiştir. Ortaokul öğrencilerinin matematik dersine yönelik genel değer algılarının orta düzeyde olduğu saptanmıştır. Benzer şekilde Türkiye' de yapılan bazı araştırmalar (Akbaş, 2014; Aktepe ve Yalçınkaya, 2016; Polat ve Çalışkan, 2013; Ünlü ve Metin, 2016) öğrencilerin bireysel ve toplumsal değerlere ilişkin algılarının yüksek olduğunu göstermektedir. Bu bağlamda Calp (2006) lise öğrencilerinin bireysel ve sosyal değerlere ilişkin değer algılarının yüksek olduğunu, Coşkun ve Yıldırım (2009) da üniversite öğrencilerinin "adalet-sayg1 ve yardımseverlik", "maddi dürüstlük" ve "doğru sözlülük" alt boyutlarından oluşan değer algılarının yüksek olduğunu saptamışlardır. Bu araştırma sonuçları dikkate alındığında 2018 yılında güncellenen ortaokul matematik öğretim programında (MEB, 2018) öne çıkarılan değerlerden olan "matematikte öz güvene sahip olma" ve "bilimsel olma" değerlerine öğretim sürecinde daha fazla yer verilmesi gerektiği ifade edilebilir.

$\mathrm{Bu}$ araştırmada kız ve erkek öğrencilerin matematik dersine yönelik değer algılarının cinsiyet bakımından anlamlı bir fark göstermediği saptanmıştır. Benzer şekilde Kabaday ve Aladağ (2010) yapmış olduğu araştırmada farklı eğitim kurumlarına devam eden erkek ve kız öğrencilerin ahlaki değer düzeyleri arasında anlamlı bir fark olmadığını tespit etmiştir. Yılmaz, Avşaroğlu ve Deniz (2010) öğretmen adaylarının değer tercihlerinin cinsiyete göre anlamlı bir fark göstermediğini saptamıştır. Bu yönüyle bu araştırmanın bulgularını destekler niteliktedir. Buna karşın yapılan bazı araştırmalar (Akbaş, 2004; Aydın, 1997; Polat ve Çalışkan, 2013; Ünlü ve Metin, 20016) kız ve erkek öğrencilerinin değer algılarında farklılaşma olduğunu göstermektedir. Ünlü ve Metin (2016), ilköğretim öğrenciler üzerinde yapmış olduğu araştırmada bilimsellik değer algısında cinsiyet bakımından anlamlı fark bulunmazken sorumluluk değer algısında kız öğrenciler lehine anlamlı bir fark olduğu saptanmıştır. Benzer şekilde Akbaş (2004) ortaokul öğrencileri üzerinde yapmış olduğu araştırmasında cinsiyete göre yardımseverlik, saygılı olmak, bilimsellik ve işbirliği yapma değer algılarında anlamlı fark olmadığını; sorumluluk, çalışkan olma, temiz olma ve çevreyi koruma değer algılarında anlamlı fark olduğunu belirlemiştir. Polat ve Çalışkan (2013) ortaokul öğrencileri ile yaptıkları araştırmada kız öğrencilerin saygılı olmak, yardımsever olmak, işbirliği yapmak, sorumluluk sahibi olmak ve çevreyi korumak değerlerinde erkek öğrencilere göre daha üst düzeyde olduklarını, buna karşın erkek ve kız öğrencilerin çalışkan olmak, bilimsel olmak ve estetik olma değer algılarında anlamlı fark olmadığını saptamışlardır. Bu sonuçlara dayalı olarak alanyazında kız ve erkek öğrencilerinin değer algılarının tutarlılık göstermediği ifade edilebilir. Bu durum her bir bireyin içinde bulunduğu aile ve sosyal çevrenin siyasal, kültürel, toplumsal bakış açısı, inanç, beklenti, yaşantı, değer verilen kişisel özellik ve davranışların değişkenlik göstermesi ile açılanabilir.

$\mathrm{Bu}$ araştırmada ortaokul öğrencilerinin matematik dersine yönelik değer algılarının sınıf bakımından farklılaştı̆̆ı, beşinci sınıf öğrencilerinin en yüksek, sekizinci sınıf öğrencilerinin ise en düşük değer algılarına sahip oldukları ve sınıf seviyesi arttıkça değer algılarının düşüş gösterdiği belirlenmiştir. Bu bulgu, öğrencilerin yaşlarının artması ile ergenlik ve özerk bir kişilik geliştirme sürecine girmeleri sonucu derse odaklanma ve uyum sorunları yaşamaları (Özdemir ve Kalaycı, 2013) ile açıklanabilir. Ayrıca sekizinci sınıf öğrencilerinin matematik değer algılarının diğer sınıflara göre daha düşük olması, Liselere Giriş Sınavının (LGS) özellikle sekizinci sınıf öğrenciler üzerinde kaygı, stres ve baskı oluşturması, bu durumun da düşük başarı gösteren öğrencilerin matematiğe yönelik olumsuz önyargı, tutum ve inanç benimsemelerine yol açmasıyla açıklanabilir. Benzer şekilde Aktepe ve Yalçınkaya (2015) yaptıkları araştırmada üçüncü sınıf öğrencilerinin hem beşinci sınıf, hem de yedinci sınıf öğrencilerine göre değerler eğitimine ilişkin uygulamalara daha fazla benimsediklerini saptamışlardır. Bu yönüyle bu araştırmanın bulgularını destekler niteliktedir. Buna karşın Coşkun ve Yıldırım (2009) üniversite öğrencileri ile yaptıkları araştırmada birinci ve dördüncü sınıf öğrencilerinin değer anlayışlarında anlamlı bir farkın 
bulunmadığını saptanmışlardır. Üniversiteye gelen öğrencilerin değer algılarının korunduğu ortaya çıkmıştır. Bu yönüyle değerler eğitiminin küçük yaştan itibaren kazandırılması gerektiği söylenebilir.

$\mathrm{Bu}$ araştırmada ortaokul öğrencilerinin matematik dersine yönelik değer algılarının yerleşim yeri bakımından anlamlı bir fark gösterdiği saptanmıştır. Buna göre il ve ilçe merkezindeki öğrencilerin köy ve beldedeki öğrencilere göre matematik değer algılarının daha yüksek olduğu belirlenmiştir. Bu durum, il ve ilçe merkezinde öğrenim gören öğrencilerin köy ve beldede öğrenim gören öğrencilere göre kültürel, sosyal ve akademik öğrenme ortamı bakımından bir çok imkana sahip olmaları (Karadeniz, 2014; Birgin ve Demirkan, 2017) ile açıklanabilir. Nitekim bu araştırma kapsamında ebeveyni üniversite mezunu olan ortaokul öğrencilerinin diğerlerine göre matematik dersine yönelik değer algılarının daha yüksek olduğu ve değer algılarının anne ve babanın eğitim düzeyi bakımından anlamlı fark gösterdiği belirlenmiştir. Araştırmanın bu bulgusu, ailenin eğitim düzeyinin ilköğretim ve ortaöğretim düzeyindeki öğrencilerin derse yönelik tutumlarına (Birgin ve Demirkan, 2017), derse bağlllık düzeylerine (Birgin ve diğ., 2017; Willms, 2003) ve akademik başarılarına (Çanakçı ve Özdemir, 2015; Öksüzler ve Sürekçi, 2010; Özer ve Anıl, 2011; Ural ve Çınar, 2014) olumlu yönde katkı yaptığını gösteren araştırma sonuçlarıyla uyum göstermektedir. Buna karşın Coşkun ve Yıldırım (2009) üniversite öğrencileri yaptığ1 araştırmada üniversite öğrencilerinin değer düzeylerinin anne ve baba eğitim düzeyine göre anlamlı bir fark göstermediğini saptamıştır. Araştırmacılar bu durumu, üniversite öğrencilerinin almış oldukları eğitim ve edindikleri yaşantı ve tecrübeler sonucunda kişisel gelişim süreçlerini ve değer yargılarını oluşturmaları ve ailenin yetişkinler üzerindeki etkisinin zayıflamasıyla açılamışlardır.

$\mathrm{Bu}$ araştırmada ortaokul öğrencilerinin matematik dersi değer algıları ile matematik başarı arasında pozitif yönlü orta düzeyde anlamlı bir ilişki saptanmıştır. Benzer şekilde alanyazındaki çeşitli araştırmalar (Aytaçlı ve Gündoğdu, 2018; Bishop, 2001; Coşkun ve Yıldırım, 2009; England, 2009; Katılmış, Ekşi ve Öztürk, 2011; Kunduroğlu, 2010) öğrencilerin değer algısının akademik başarılarını olumlu yönde etkilediğini vurgulamaktadır. Bu bağlamda Aytaçlı (2018) yaptığı araştırmasında değer temelli öğretimin öğrencilerin matematik başarısına ve matematik yönelik tutumuna olumlu yönde katkı sağladığını belirlemiştir. Çeliköz ve Duran (2017) sekizinci sınıf öğrencileri üzerinde yaptıkları araştırmada öğretmenin sınıf içindeki ve dışındaki davranışlarının öğrencilerin matematik başarısı üzerinde oldukça etkili olduğunu tespit etmişlerdir. Ayrıca yapılan birçok araştırma (Birgin ve diğ., 2017; Birgin ve Demirhan, 2017; Balantekin ve Oksal, 2014; Kemanc1, 2004; Nicolaidou ve Philippou, 2003; Peker ve Mirasyedioğlu, 2003; Singh, Granville ve Dika, 2002) öğrencilerin matematik dersine yönelik duyuşsal hedeflere (tutum, öz-yeterlik, bağllık, ilgi ve motivasyon gibi) önem ve değer vermelerinin akademik başarılarını artırdığını ortaya koymaktadır. Bu araştırmanın sonucu ve ülkemizdeki öğrencilerin ulusal ve uluslararası matematik sınavlarında başarı düzeyinin düşüklüğü dikkate alındığında öğrencilerinin matematik başarısının artırılması bağlamında öğretim sürecinde matematik dersine yönelik değerlere daha çok önem verilmesi gerektiği söylenebilir.

$\mathrm{Bu}$ araştırmada öğrencilerin matematik dersine yönelik değer algısı ile matematik dersi öğretmenini sevme ve matematik dersi önem verme arasında pozitif yönlü orta düzeyde anlamlı bir ilişki olduğu saptanmışır. Alanyazındaki birçok araştırma sonucu, bu araştırmanın sonucunu destekler niteliktedir. Martin ve Rimm-Kaufman (2015) beşinci sınıf öğrenciler üzerinde yaptıkları araştırmada öğretmen ile öğrenci arasındaki etkili etkileşimin öğrencinin duyuşsal ve sosyal düzeylerini artırdığını saptamışlardır. Benzer şekilde matematik dersine önem verme düzeyi ile matematik tutumu ve başarıları arasında pozitif yönlü (Birgin ve Demirkan, 2017; Kemancı, 2004), matematik kaygısı arasında ise negatif yönlü anlamlı bir ilişkinin olduğu (Birgin ve diğg., 2010) saptanmıştır. Öğrencilerin matematik değer algılarının arttırılması bağlamında öğretmenlerinin matematik derslerini öğrencilerin ilgisini çekecek ve öğrenmeye motive edecek nitelikte etkinliklerle desteklemesi ve öğretmen-öğrenci arasında iyi bir iletişim kurması gerektiği ifade edilebilir.

Araştırma kapsamında ortaokul öğrencilerinin matematik dersine yönelik değer algılarını bazı değişkenler bakımından incelenmiştir. Bundan sonraki çalışmalarda farklı öğretim kademelerinde öğrencilerinin matematik dersine yönelik değer algılarını farklı değişkenler bakımından incelenebilir. 
Ayrıca matematik öğretmenlerinin öğretim sürecinde değer eğitimine yönelik uygulamaları ne düzeyde gerçekleştirdikleri detaylı olarak araştırılabilir.

\section{Kaynakça}

Akbaş, O. (2004). Türk milli eğitim sisteminin duyuşsal amaçlarının ilköğretim II.kademedeki gerçekleşme derecesinin değerlendirilmesi (Yayımlanmamış doktora tezi). Gazi Üniversitesi, Eğitim Bilimleri Enstitüsü, Ankara.

Akbaş, O. (2008). Değer eğitimi akımlarına genel bir bakış. Değerler Eğitimi Dergisi, 6(16), 9-27.

Aktaş, F. N. ve Argün, Z. (2018). Sınıf uygulamalarında matematiğe ilişkin değerlerin incelenmesi: Ortaöğretim matematik öğretmenlerinin bir durum çalışması. Eğitim ve Bilim, 43(193), 121-142.

Aktepe, V. ve Yalçınkaya, E. (2016). Okul ortamında değerler eğitiminin öğrenci görüşlerine göre çeşitli değişkenler açısından incelenmesi. Kırşehir Eğitim Fakültesi Dergisi, 17(2), 113-131.

Aydın, Y. (1997). İlköğretim 4, 5 ve 6. sınıföğrencilerinin cinsiyet açısından sahip oldukları değerlerin incelenmesi (Yayınlanmamış yüksek lisans tezi). Marmara Üniversitesi, Eğitim Bilimleri Enstitüsü, İstanbul.

Aytaçlı, B. (2018). Değer temelli etkinliklerin matematik başarısına, değer algısına, problem çözme becerisine, matematiğe yönelik tutuma ve kalıcllğa etkisi (Yayınlanmamış yüksek lisans tezi). Adnan Menderes Üniversitesi, Sosyal Bilimler Enstitüsü, Aydın.

Aytaçlı, B. ve Gündoğdu, K. (2019). Matematik uygulamaları dersi değer algısı ölçeği geçerlik ve güvenirlik çalışması. Gazi Üniversitesi Gazi Ĕ̆itim Fakültesi Dergisi, 39(1), 171-191.

Baki, A. (2008). Kuramdan uygulamaya matematik eğitimi. Ankara: Harf Yayınları

Balantekin, Y. ve Oksal, A. (2014). İlkokul 3. ve 4. sınıf öğrencileri için matematik dersi motivasyon ölçeği. Cumhuriyet Uluslararası Ĕ̆itim Dergisi, 3(2), 102-113.

Birgin, O. (2016). Matematik öğrenmeye ilişkin inanç ölçeğinin geliştirilmesi: Geçerlik ve güvenirlik çalışması. Proceedings of First INES International Academic Research Congress (ss. 3663-3670). Ankara: Pegem Akademi Yayıncılık.

Birgin, O. ve Demirkan, H. (2017). Yatılı bölge ortaokulu öğrencilerinin matematiğe yönelik tutumlarının bazı değişkenler bakımından incelenmesi. e-Uluslararası Eğitim Araştırmaları Dergisi, 8(2), 1-15.

Birgin, O., Baloğlu, M., Çatlığlu, H., \& Gürbüz, R. (2010). An investigation of mathematics anxiety among sixth through eighth grade students in Turkey. Learning and Individual Differences, 20(6), 654658. https://doi.org/10.1016/j.lindif.2010.04.006

Birgin, O., Mazman Akar, S. G., Uzun, K., Göksu, B., Peker, E. S., \& Gümüş, B. (2017). Investigation of factors affected to mathematics engagement of middle school students. International Online Journal of Educational Sciences, 9(4), 1093-1110. https://doi.org/10.15345/iojes.2017.04.014

Bishop, A. J. (2001). What values do you teach when you teach mathematics? Teaching Children Mathematics, 7(6), 346-349.

Bishop, A., Clarke, B., Corrigan, D., \& Gunstone, D. (2005). Teachers' preferences and practices regarding values in teaching mathematics and science. Building Connections: Research, Theory and Practice, 1, 153-160.

Bishop, A., Seah, W. T., \& Chin, C. (2003). Values in mathematics teaching - The hidden persuaders?. In Second international handbook of mathematics education (pp. 717-765). Dordrecht: Springer.

Calp, Ö. (2006). Lise son sımı öğrencilerinin sosyal değerlere bakışlarının incelenmesi (Hatay-merkez ilçe örneği) (Yayınlanmamış yüksek lisans tezi). Gazi Üniversitesi, Eğitim Bilimleri Enstitüsü, Ankara.

Coşkun, Y. ve Yıldırım, A. (2009). Üniversite öğrencilerinin değer düzeylerinin bazı değişkenler açısından incelenmesi. Yüzüncü Yıl Üniversitesi Ĕ̆itim Fakültesi Dergisi, 6(1), 311-328. 
Çanakçı, O. ve Özdemir, A. Ş. (2015). Matematik başarısı ve anne baba eğitim düzeyi. İstanbul Aydın Üniversitesi Dergisi, 7(25), 19-36.

Çelik, D., Özmen, Z., Aydın, S., Güler, M., Birgin, O., Açıkyıldız, G., Gürsoy, K., Arabacı, D., Güneş, G., \& Gürbüz, R. (2018). A national comparison of pre-service elementary mathematics teachers' beliefs about mathematics: The case of Turkey. Education and Science, 43(193), 289-315.

Çeliköz, N. ve Duran, B. (2017). Öğretmen davranışlarının matematik başarısı üzerindeki etkisinin 8. sınıf öğrenci görüşleri bağlamında incelenmesi. Ahi Evran Üniversitesi Kırşehir Eğitim Fakültesi Dergisi, 18(3), 564-585.

Çevirgen, A. E. (2016). İlköğretim matematik öğretmen adaylarının matematik ve matematik eğitimine yönelik inançları. Mehmet Akif Ersoy Üniversitesi Ĕ̆itim Fakültesi Dergisi, 39, 37-57.

Dede, Y. (2007). Matematik öğretiminde değerlerin yeri. Abant İzzet Baysal Üniversitesi Eğitim Fakültesi Dergisi, 7, 11-19.

Dede, Y. (2013). Türk ve Alman matematik öğretmenlerinin grup çalışmalarındaki karar verme süreçlerinin altındaki değerlerin incelenmesi. Kuram ve Uygulamada Eğitim Bilimleri, 13(1), 671-706.

Deniz, D. (2018). Matematik öğretim programında yer alan değerler eğitimine yönelik öğretmen görüşlerinin incelenmesi. OPUS-Uluslararası Toplum Araştırmaları Dergisi, 9(16), 678-705. https://doi.org/10.26466/opus.476727

Durmuş, S., Bıçak, B. ve Çakır, S. (2008). Fen ve teknoloji, matematik ve sınıf öğretmenlerinin sahip oldukları matematik ve matematik eğitimi değerlerinin farklı değişkenler açısından incelenmesi. Değerler Eğitimi Dergisi, 6(16), 93-112.

England, T. F. (2009). Character education and the perceived impact on student akademik achievement and in fazilitating a safe and effective learnin enviroment in California K-12 public schools (Unpublished Doctorate Thesis). University of La Verne, California, USD.

Güngör, E. (2010). Değerler psikolojisi üzerinde araştırmalar. İstanbul: Ötüken Yay.

Halstead, J. M., \& Taylor, M. J. (2000). Learning and teaching about values: A review of recent research. Cambridge Journal of Education, 30(2), 169-202.

İlhan, M. ve Çetin, B. (2013). Matematik odaklı epistemolojik inanç ölçeği (MOEİÖ): Geçerlik ve güvenirlik çalışması. Kuramsal Ĕ̆itimbilim Dergisi, 6(3), 359-388.

Kabaday, A. ve Aladağ, K. S. (2010). Farklı ilköğretim kurumlarına devam eden öğrencilerin ahlaki gelişimlerinin çeşitli değişkenler açısından değerlendirilmesi. Uluslararası İnsan Bilimleri Dergisi, 7, s. $878-898$.

Karadeniz, İ. (2014). Kırsal kesimdeki ortaokul öğrencilerinin matematiğe ilişkin kaygılarn ile matematik tutumları arasındaki ilişki (Yayınlanmamış yüksek lisans tezi). Eskişehir Osmangazi Üniversitesi, Eğitim Bilimleri Enstitüsü, Eskişehir.

Karasar, N. (2004). Bilimsel araştırma yöntemleri. Ankara: Nobel Yayıncılık.

Katılmış, A., Ekşi, H. ve Öztürk, C. (2011). Sosyal bilgiler ders kazanımlarıyla bütünleştirilmiş karakter eğitimi programının etkililiği. Kuram ve Uygulamada Ĕ̆itim Bilimleri, 11 (2), 839-859.

Kemanc1, Z. (2004). Muğla ili Ortanca ilçesi ilköğretim II.kademe öğrencilerinin matematik dersine yönelik tutumlarının değerlendirilmesi (Yayınlanmamış yüksek lisans tezi). Muğla Üniversitesi, Sosyal Bilimler Enstitüsü, Muğla.

Kızılçelik, S. ve Ejder, Y. (1994). Açıklamalı sosyoloji terimler sözlüğü̈. Ankara: Atilla Kitapevi. 
Kunduroğlu, T. (2010). 4.sınıf fen ve teknoloji dersi öğretim programıyla bütünleştirilmiş "değerler eğitimi" programının etkililiğinin incelenmesi (Yayınlanmamış yüksek lisans tezi). Ankara Üniversitesi, Ankara.

Martin, D. P., \& Rimm-Kaufman, S. E. (2015). Do student self-efficacy and teacher-student interaction quality contribute to emotional and social engagement in fifth grade math? Journal of School Psychology, 53(5), 359-373. https://doi.org/10.1016/j.jsp.2015.07.001

Milli Eğitim Bakanlığı (MEB) (2005). Illköğretim okulu matematik dersi (6-8. sinıflar) öğretim programı. Ankara: Talim Terbiye Kurulu Başkanlığı.

Milli Eğitim Bakanlığı (MEB) (2009). Illköğretim matematik dersi 6-8. sınıflar öğretim programı. Ankara: Talim ve Terbiye Kurulu Başkanlığı.

Milli Eğitim Bakanlığı (MEB) (2013). Ortaokul ve imam hatip ortaokulu matematik uygulamaları dersi (5, 6, 7 ve 8. sinıflar) öğretim programı. Ankara: Talim ve Terbiye Kurulu Başkanlığı.

Milli Eğitim Bakanlığı (MEB) (2018). Matematik dersi öğretim programı (Illkokul ve Ortaokul 1, 2, 3, 4, 5, 6 , 7 ve 8. sinıflar). Ankara: Milli Eğitim Bakanlı̆̆ı.

National Council of Teachers of Mathematics (NCTM) (2000). Principles and standards for school mathematics. Reston, VA: NCTM.

Nicolaidou, M., \& Philippou, G. (2002). Attitudes towards mathematics, self efficacy and achievement in problem solving. European Research in Mathematics Education, 3, 1-10.

Öksüzler, O. ve Sürekçi, D. (2010). İlköğretimde başarıyı etkileyen faktörler: Bir sıralı lojit yaklaşımı. Finans Politik \& Ekonomik Yorumlar, 47 (543), 93-103.

Özdemir, M. ve Kalaycı, H. (2013). Okul bağlılığı ve metaforik okul algısı üzerine bir inceleme: Çankırı ili örneği. Kuram ve Uygulamada Eğitim Bilimleri, 13(4), 2125-2137.

Özer, Y. ve Anıl, D. (2011). Öğrencilerin fen ve matematik başarılarını etkileyen faktörlerin yapısal eşitlik modeli ile incelenmesi. Hacettepe Üniversitesi Ĕ̆itim Fakültesi Dergisi, 41, 313-324.

Peker, M. ve Mirasyedioğlu, Ş. (2003). Lise 2.sınıf öğrencilerinin matematik dersine yönelik tutumları ve başarıları arasındaki ilişki. Pamukkale Üniversitesi Eğitim Fakültesi Dergisi, 14, 157-166.

Peker Ünal, D. ve Şen, E. Ö. (2019). İlköğretim matematik öğretmen adaylarının tasarladıkları materyallerle öğretim programında yer alan değerlerin ilişkilendirilmesi. Değerler Eğitimi Dergisi, 17 (37), 77-107. https://doi.org/10.34234/ded.456619

Polat, S. ve Çalışkan, M. (2013). Ortaokul öğrencilerinin değer yönelimlerinin bazı değişkenler açısından incelenmesi. Uludağ Üniversitesi Eğitim Fakültesi Dergisi, 26(2), 387-404.

Sam, L., \& Ernest, P. (1997). Values in mathematics education: what is planned and what is espoused. In Proceedings of the Day Conference held at University of Nottingham (pp.37-44). British Society for Research into Learning Mathematics (BSRLM).

Seah, W. T., \& Bishop, A. J. (2003). Values, mathematics and society: making the connections. Prime Number, 18(3), 4-9.

Singh, K., Granville, M., \& Dika, S. (2002). Mathematics and science achievement: Effects of motivation, interest, and academic engagement. The Journal of Educational Research, 95(6), 323-332.

Swadener, M., \& Soedjadi, R. (1988). Values, mathematics education, and the task of developing pupils' personalities: An Indonesian perspective. In Mathematics education and culture (pp. 193-208). Springer, Dordrecht.

Ural, A. ve Çınar, F. N. (2014). Anne ve babanın eğitim düzeyinin öğrencinin matematik başarısına etkisi. Mehmet Akif Ersoy Üniversitesi Ĕ̆itim Bilimleri Enstitüsü Dergisi, 3(4), 41-56. 
Ünlü, İ. ve Metin, Ö. (2016). İlköğretim öğrencilerinin cinsiyet değişkenine göre değerlere ulaşma düzeyleri. Kırşehir Ĕ̆itim Fakültesi Dergisi, 17(2), 697-173

Willms, J. D. (2003). Student engagement at school: A sense of belonging and participation: Results from PISA 2000. Paris: Organization for Economic Co-operation and Development.

Yazıcı, M. (2014). Değerler ve toplumsal yapıda sosyal değerlerin yeri. Fırat Üniversitesi Sosyal Bilimler Dergisi, 24(1), 209-223.

Yılmaz, E., Avşaroğlu, S., \& Deniz, M. (2010). An investigation of value preferences of teacher candidates. Procedia-Social and Behavioral Sciences, 2(2), 4943-4948. 